\title{
STUDI PENGUKURAN AKTIVITAS ANAK LURUH U-238, TH-232 DAN K-40 DALAM FILTER PM 10 DAN PM 2,5 DI DAERAH - JATENG II
}

\author{
Muzakky, Agus Taftazani \\ Pusat Teknonogi Akselator dan Proses Bahan, Jl.Babarsari kp 6101 ykbb, Yogyakarta, 55281. \\ e-mail : ptapb@batan.go.id
}

Diterima 27 Desember 2011, diterima dalam bentuk perbaikan 6 Pebruari 2012, disetujui 9 Pebruari 2012

\begin{abstract}
ABSTRAK
STUDI PENGUKURAN AKTIVITAS ANAK LURUH U-238, Th-232 DAN K-40 DALAM FILTER PM 10 DAN PM 2,5 DI DAERAH - JATENG II. Telah dilakukan studi pengukuran aktivitas anak luruh U-238 dan Th-232 dan K40 dalam filter PM10 dan PM2,5 didaerah Jateng II. Penelitian ini bertujuan (1) melakukan prediksi jarak sampling dan stabilitas meteorologi dan (2) identifikasi aktivitas radionuklida yang terdapat pada filter udara PM 2,5 dan PM 10 di daerah perkotaan. Dengan memakai perangkat lunak "SCREEN3" dan "WRPLOT" sampling udara di daerah sekitar PLTU Jateng II dapat ditentukan pada bulan Juni 2011 dengan jarak sampling diantara $1300 \mathrm{~m}-1500 \mathrm{~m}$. Hasil prediksi stablitas meteorologi di bulan Juni 2011 yang dibuat dengan pemodelan memakai "SCREEN3" diperkirakan diantara mempunyai tipe B, B-C , C dan sedikit kearah tipe D. Hasil aktivitas filter PM 10 dan PM 2,5 di ketiga tempat pengambilan sampling menggunakan spektrometer gamma, ternyata ditemukan juga 6 macam radionuklida yaitu Ac-228, TI-208, Pb-212, Ra-226, Bi-214 dan K-40. Dari hasil perhitungan diperoleh bahwa aktivitas radionuklida tertinggi pada sampel udara PLTU Jateng II untuk PM 2,5 dan PM 10 adalah Ra-226 dengan masing-masing aktivitas antara 0,04 -0,06 Bq/ $/ \mathrm{m}^{3}$ udara.
\end{abstract}

Kata kunci : SCREEN3, WRPLOT, PM 2,5 dan PM 10.

\begin{abstract}
A STUDY ON MEASUREMENT OF U-238, Th-232 AND K-40 DECAY IN PM 10 AND PM 2,5 FILTERS AT THE $2^{\text {nd }}$ AREA CENTRAL JAVA. A studies on measurement of U-238 and Th-232 and K-40 decay in PM 10 and PM 2,5 filters at area II Central of Jawa have been done. The aim of studies are to (1) Prediction of sampling distances and meteorologists stability (2) identification of radionuclides activity on PM 10 and PM 2,5 filter of air in urban area. By "SCREEN3" and "WRPLOT" software the air sampling in coal fire power plant vicinity could be determined at June of 2011 and distance of sampling among $1300 \mathrm{~m}-1500 \mathrm{~m}$. The results of meteorologists stability in June of 2011 that made by" SCREEN3" models was estimated have B, B-C, C type, or few toward D type. The result of activities PM 10 and PM 2,5 filters in the third of the sampling places using gamma spectrometer, it was found 6 radionuclides there are Ac-228, TI-208, Pb-212, Ra-226, Bi-214 and K-40. From calculation was obtained that the highest of radionuclide in PM 10 and PM2,5 were Ra-226 with activity between $0,04-0,06 \mathrm{~Bq} / \mathrm{m}^{3}$ air.
\end{abstract}

Keyword : SCREEN3, WRPLOT, PM 2,5 and PM 10

\section{PENDAHULUAN}

Dolusi atmosfir di daerah sekitar Pusat Listrik Tenaga Uap (PLTU) memakai bahan bakar batubara akhir-akhir ini telah banyak menarik para pemerhati lingkungan, karena semakin turunnya kualitas udara. Sementara target pemerintah tahun 2010 adalah tersedianya pasokan listrik $10.000 \mathrm{MW}$ dan tahun 2020 sebesar 20.000 MW dari PLTU-Batubara, dengan sekitar $65 \%$ untuk Jawa-Bali dengan rencana lokasi PLTU baru di Jawa (1). Dengan demikian daya dukung udara atmosfir di Jawa akan semakin menurun, terutama daerah yang berdekatan PLTU-batubara tersebut. Masalah penurunan daya dukung udara atmosfir ini telah membuat para pakar lingkungan untuk membandingkan pembangkit listrik PLTU dengan PLTN (Pusat Listrik Tenaga Nuklir). 
Menurut HENI ${ }^{(2)}$, PLTU batubara akan menghasilkan produk yang lebih radioaktif dibandingkan dengan PLTN, karena tingginya keluaran jumlah radon, uranium dan torium dari cerobong PLTU batubara. Sementara itu beberapa jenis radionuklida yang dikeluarkan PLTU-batubara berupa Ra-226, Ra-228, Th-228, Th-230, Th-232, Po-210, Pb-210 dan Ac-227, sedangkan PLTN hanya radionuklida I-131 itupun pada jenis reaktor BWR (Boilng Water Reactor). Menurut MAROVIC ${ }^{(3)}$, telah mengukur radioaktivitas abu dasar dan abu layang PLTU-Plomin, dan mendapatkan aktivitas anak luruh U-238 dan Th-232 telah melebihi batas ambang untuk lingkungan yang di syaratkan oleh UNSCEAR (2000). Sehingga perlu dilakukan monitoring menyeluruh secara periodik dampak terhadap pekerja dan lingkungan di PLTU -Plomin Northern Adriatic. FLUES. ${ }^{(4)}$., menentukan aktivitas U-238, Ra-226, Pb-210, Th-232 dan K-40 di dalam batubara dan abu layang PLTU-Figuera Brazil, untuk mengevaluasi dis equilibrium dan faktor pengayakan radionuklida di setiap proses pembakaran batubara. PAPASTEFANOU. ${ }^{(5)}$, telah mengukur aktivitas radionuklida batubara dari tambang di Greece misalnya sangat bervariasi dari 117 $435 \mathrm{~Bq} \mathrm{~kg}^{-1}$ untuk U-238, 44 - $255 \mathrm{~Bq} \mathrm{~kg}^{-1} \mathrm{Ra}-226,59-205 \mathrm{~Bq} \mathrm{~kg}^{-1} \mathrm{~Pb}-210,9$ - 41 Bq kg${ }^{-1}$ Ra-228 (Th-232) dan 59 - $227 \mathrm{~Bq} \mathrm{~kg}{ }^{-1}$ untuk K-40. Sementara itu aktivitas abu layang yang dikeluarkan dari cerobong menjadi 263 950 Bq kg ${ }^{-1}$ untuk U-238, 142 - 605 Bq kg-1 Ra-226, 133 - $428 \mathrm{~Bq} \mathrm{~kg}^{-1} \mathrm{~Pb}-210,27$ - 68 Bq kg${ }^{-1} \mathrm{Ra}-228$ (Th-232) dan $204-382 \mathrm{Bqkg}^{-1}$ untuk K-40. Dengan demikian, konsentrasi radionuklida di dalam abu layang juga akan bervariasi dan cenderung lebih kaya dibandingkan unsur radionuklida yang terkandung di dalam batubara. Jadi permasalahan pencemaran udara atmosfir didaerah sekitar PLTU akibat adanya abu layang diatas akan segera munculkan masalah seperti infeksi saluran pernafasan atas (ISPA), iritasi kulit hingga kanker paru telah dilaporkan beberapa puskesmas daerah Cilacap yang berdekatan dengan PLTU- Jateng ${ }^{\left({ }^{(6)}\right.}$. SAYED ${ }^{(7)}$, telah mengukur $\mathrm{Pb}-210$ di udara atmosfir kota Kuwait, dan mendapatkan distribusi harian $\mathrm{Pb}-210$ diantara 0,002 $2,53 \mathrm{mBq} / \mathrm{m}^{3}$ dan rata-rata $0,896 \mathrm{mBq} / \mathrm{m}^{3} . \mathrm{KAM} . \mathrm{E}^{(8)}$, telah mengukur outdoor radiasi gamma di sekitar provinsi Canakkale, Turkey sebesar 66,4 nGy.h ${ }^{-1}$, yang diakibatkan oleh U-238, Th-232 dan K-40. Kemudian CEVIK..$^{(9)}$, telah dilakukan identifikasi NORM seperti ${ }^{226} \mathrm{Ra},{ }^{232} \mathrm{Th}$ dan ${ }^{40} \mathrm{~K}$ di Ankara Turey coal power plant, yang aktivitasnya rata-rata $57,82,30,45$ and $322,21 \mathrm{~Bq} \cdot \mathrm{kg}^{-1}$. Maka studi untuk mengetahui beberapa aktivitas radionuklida polutan udara, khususnya terhadap anak luruh U-238, Th-232 dan K-40 sangat menarik untuk dilakukan oleh beberapa ilmuwan. Pada penelitian ini akan dilakukan studi aktivitas radionuklida polutan udara di daerah PLTU-JATENG II. Penelitian ini sengaja akan diawali dengan melakukan kegiatan presampling untuk mengetahui jarak sampling, dan prediksi stabilitas meteorologi menggunakan perangkat lunak masing-masing "SCREEN3" dan "WRPLOT" $(10,11)$. Selanjutnya penelitian ini akan memakai alat High Volume Air Sampler (HVS) model TFIA-2, CKHV810 STAPLEX Air Sampler buatan U.S.A, filter dipakai jenis TFA810 glass fiber 8"X10" untuk pengambilan pertikulat PM 2,5 dan PM 10, selanjutnya indentifikasi radionuklida alam memakai spektrometri Gamma ${ }^{(12)}$. Secara keseluruhan metoda penelitian ini mengadopsi "The International Monitoring System of the Comprehensive Nuclear Test Ban Treaty Organization (CTBTO)"(13,14,15,16), tentang tata cara sampling dan identifikasi radionuklida baik akibat foulout ataupun oleh industri. Maka tujuan penelitian ini adalah (1) melakukan prediksi jarak sampling dan stabilitas meteorologi pada hari $\mathrm{H}$ (dilakukannya sampling) dan (2) identifikasi dan asesmen radionuklida yang terdapat pada filter udara PM 2,5 dan PM 10 hasil sampling di daerah PLTU-Jateng II. Penelitian ini diharapkan memberi masukan kepada pihak berwenang tentang kualitas udara di sekitar PLTU Jateng II.

\section{METODOLOGI}

\section{Lokasi Sampling}

Lokasi sampling dipilih di PLTU-Jateng II, dan tepatnya di desa Karangkandri dan Menganti Kecamatan Kesugihan kabupaten Cilacap, provinsi Jawa Tengah. Pengambilan sampel udara dilakukan pada musim kemarau tanggal 14-19 juni 2011. Dipilih tiga 3 lokasi sampling masing-masing dengan koordinat geograpi,

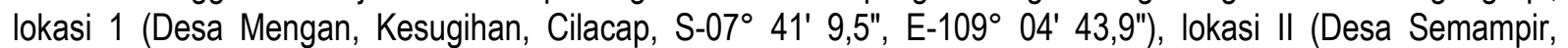
Slarang, Kesugihan, Cilacap S $07^{\circ} 40^{\prime}$ 35,4", E-109 05' 52,2") dan lokasi III (Desa Karang Dadap, Karangkandri, $\left.\mathrm{S} 07^{\circ} 40^{\prime} 38,7^{\prime \prime}, \mathrm{E} 109^{\circ} 04^{\prime} 55,1^{\prime \prime}\right)$. Berikut peta dari pengambilan sampel udara. 


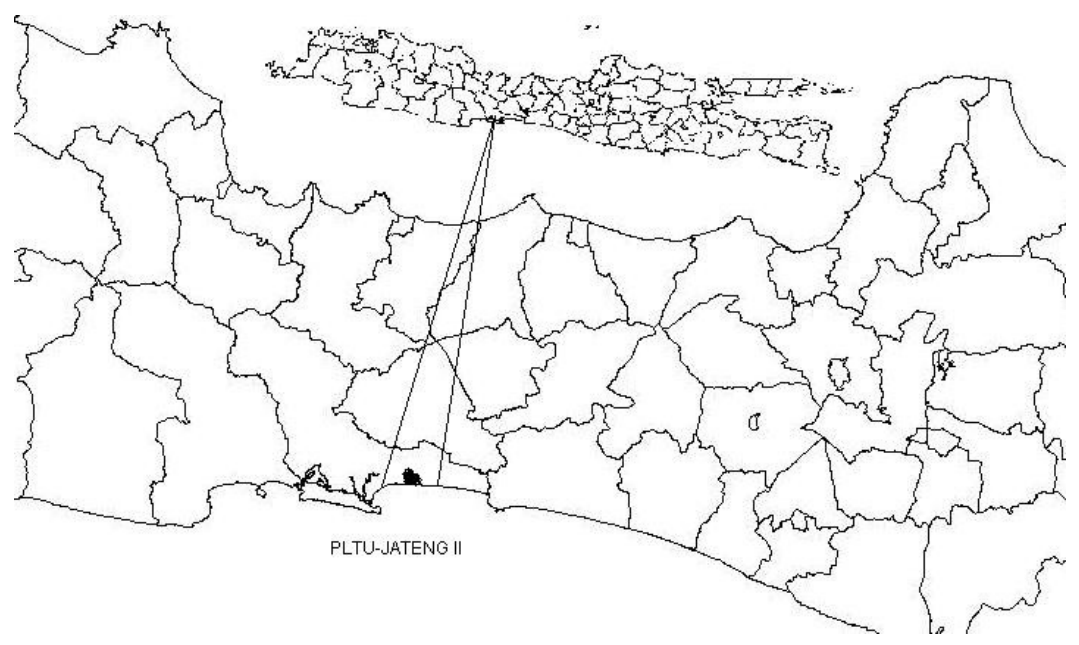

Gambar 1. Lokasi sampling PLTU-Jateng II

\section{Rancangan Penelitian}

Perancangan penelitian ini meliputi beberapa tahap seperti skema berikut,

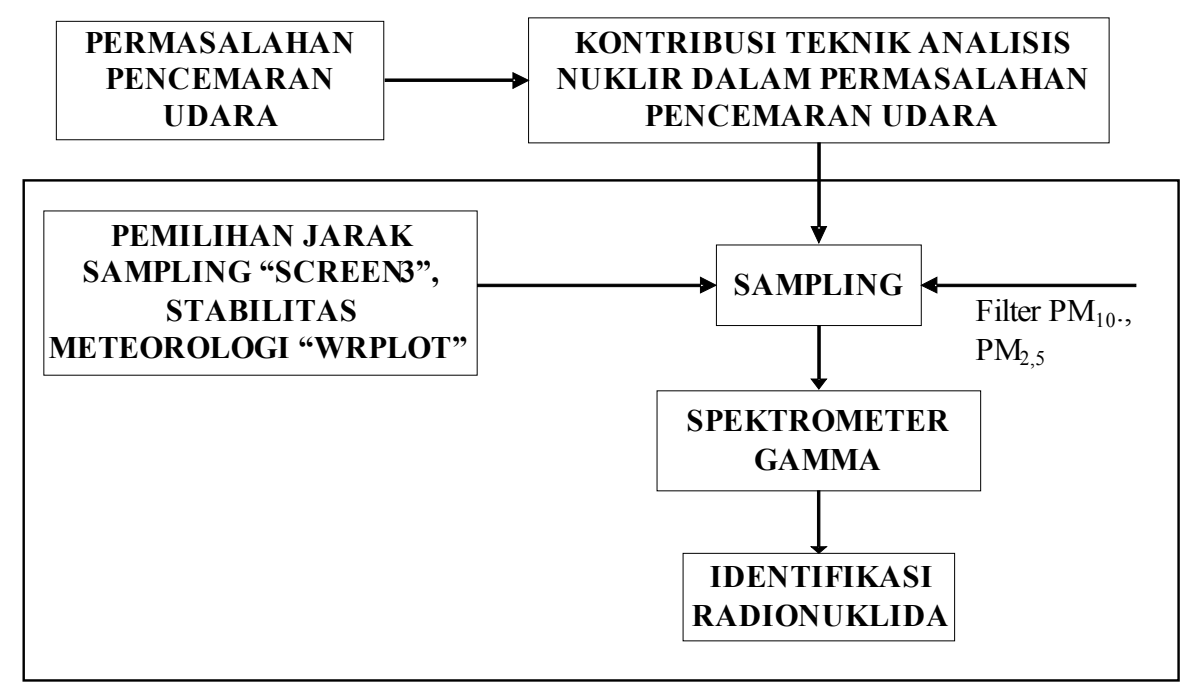

Gambar 2. Sketsa perancangan tahap-tahap kegiatan penelitian

\section{Presampling}

Dalam rangka penentuan waktu sampling dan lokasi pengambilannya penelitian ini memakai perangkat lunak SCREEN3 View dan WRPLOT yang masing masing dapat di unduh di website http://www.weblake.com ${ }^{(10,}$ 11). Perangkat lunak SCREEN3 View digunakan untuk mempredikasi konsentrasi polutan udara yang dikeluarkan oleh cerobong PLTU, dengan keunggulan beberapa pilihan skenario yang simple atau compleks terrain, dengan atau tanpa pengaruh ketinggian gedung, dan memberikan pilihan hasil jarak secara manual ataupun outomatik. Jadi preliminary sampling modelling dengan SCREEN3 View tersebut akan menghemat waktu, dana dan tenaga dalam pengambilan sampling udara. Sementara perangkat lunak WRPLOT dapat memprediksi kecepatan dan arah angin pada waktu pengambilan udara di lokasi sampling. Hasil perangkat lunak WRPLOT berupa grafik cakra angin yang berupa visualisasi disetiap arah angin secara spesifik, dan klasifikasikan kecepatan angin untuk setiap arah lokasi dan periode waktunya. 


\section{Sampling}

Pengambilan sampel udara dilakukan pada musim kemarau, dari tanggal 14-19 juni 2011, memakai alat High Volume Air Sampler (HVS) model TFIA-2, CKHV810 STAPLEX Air Sampler buatan U.S.A, filter dipakai jenis TFA810 glass fiber 8"X10" sesuai syarat pengambil PM10 dan PM 2,5 dan alat dioperasikan dengan kecepatan alir $10 \mathrm{~m}^{3} / \mathrm{jam}$. Secara keseluruhan metoda penentuan aktivitas Technological Enhanched Naturally Occurring Radioactive Material (TENORM) dalam filter PM10 dan PM 2,5, dilakukan dengan mengadopsi The International Monitoring System of the Comprehensive Nuclear Test Ban Treaty Organization (CTBTO) ${ }^{(13,14,15,16)}$

\section{Spektrometri Gamma}

Sampel PM 10 dan PM 2,5 hasil sampling udara akan ditentukan anak luruh U-238, Th-232 dan K-40 dengan spektrometri gamma, dengan sistem detektor Ge(Li) ORTEC, model no.8001-1026-WS dengan aktif volume sebesar $48.7 \mathrm{~cm}^{3}$. Spektrometer gamma tersebut mempunyai total resolution sebesar $3.91 \mathrm{keV} \mathrm{FWHM}$ dan relatif efisiensi deteksi sebesar $10.6 \%$. Selanjutnya jarak sampel dengan detektor diatur berkisar $\pm 25 \mathrm{~cm}$, dan detektor ditempatkan di tengah-tengah wadah timbal ("shelding") berbentuk kubus dengan ketebalan timbal $20 \mathrm{~cm}$, panjang $80 \mathrm{~cm}$, lebar $80 \mathrm{~cm}$ dan tinggi $100 \mathrm{~cm}$. Setiap sampel PM 10 dan PM 2,5 diukur anak luruh U238, Th-232 dan K-40 selama 24 jam ${ }^{(13,14,15,16)}$. Intensitas energi sinar gamma yang digunakan untuk menghitung masing-masing anak luruh U-238, Th-232 dan K-40, masing-masing adalah tenaga $93.1 \mathrm{keV}\left({ }^{234} \mathrm{Th}\right)$, 186.2keV( $\left.{ }^{226} \mathrm{Ra}\right), 239.3 \mathrm{keV}\left({ }^{212} \mathrm{~Pb}\right), 510.2 \mathrm{keV}\left({ }^{208} \mathrm{TI}\right), 610.2 \mathrm{keV}\left({ }^{214} \mathrm{~Pb}\right), 1460 \mathrm{keV}\left({ }^{40} \mathrm{~K}\right)$ and $1764 \mathrm{keV}\left({ }^{214} \mathrm{Bi}\right)$. Perangkat lunak komputer Maestro II dengan model A64-BI yang telah dikembangkan oleh EG\&G ORTEC, digunakan untuk mengevaluasi spektra radionuklida yang muncul. Dengan daerah kerja energi yang berkisar diantara $41 \mathrm{keV}$ - $2810 \mathrm{keV}$, spektrometri gamma tersebut cukup memberikan daerah kerja yang proportional untuk mengukur aktivitar Naturally Occurring Radioactive Material (NORM) di dalam fiter PM 10 dan PM 2,5.

\section{HASIL DAN PEMBAHASAN}

\section{Prediksi Jarak Sampling}

Langkah pertama untuk memprediksi jarak sampling dilakukan dengan mengetahui konsentrasi polutan udara di tingkat ground level yang dikeluarkan oleh cerobong PLTU-Jateng II yaitu dengan mengasumsikan bahwa radionuklida yang dikeluarkan oleh cerobong PLTU berupa sumber tunggal. Selanjutnya dilakukan empat skenario yaitu (1) variasi tinggi cerobong $(\mathrm{m}),(2)$ kecepatan laju alir emisi gas buang(m/s), (3) diameter cerobong $(\mathrm{m})$ dan $(4)$ temperatur gas buang $\left({ }^{\circ} \mathrm{K}\right)$. Dengan prediksi bahwa ketinggian cerobong PLTU - Jateng II diperkirakan diantara 180-210 meter, maka dipilih variasi tinggi cerobong dari $180 \mathrm{~m}$ hingga $240 \mathrm{~m}$. Pemilihan ke empat skenario tersebut dipilih berdasarkan pada peraturan pemerintah No. 205 tahun 1996 merupakan faktor utama pada pengendalian pencemaran udara dari sumber yang tidak bergerak. Pada Tabel 1 berikut berikut merupakan hasil simulasi pemodelan memakai perangkat lunak SCREEN3 dengan pemilihan daerah urban.

Tabel 1. Hasil pemodelan dengan skenario tinggi cerobong 180 meter dengan variasi diameter dan variasi kecepatan alir gas buang pada temperatur $323^{\circ} \mathrm{K}$

\begin{tabular}{|c|c|c|c|c|c|c|}
\hline \multirow{2}{*}{ SKENARIO } & \multicolumn{3}{|c|}{ Diameter Cerobong $(\mathrm{m})$} \\
\cline { 2 - 7 } & \multicolumn{2}{|c|}{10} & \multicolumn{2}{c|}{20} & \multicolumn{2}{c|}{30} \\
\hline $\begin{array}{c}\text { Kecepatan laju alir } \\
\text { emisi gas buang } \\
(\mathrm{m} / \mathrm{dt})\end{array}$ & $\begin{array}{c}\text { Kons. Maks } \\
\left(\mu \mathrm{g} / \mathrm{m}^{3}\right)\end{array}$ & $\begin{array}{c}\text { Jarak Kons. } \\
\text { Maks }(\mathrm{m})\end{array}$ & $\begin{array}{c}\text { Kons. Maks } \\
\left(\mu \mathrm{g} / \mathrm{m}^{3}\right)\end{array}$ & $\begin{array}{c}\text { Jarak Kons. } \\
\text { Maks }(\mathrm{m})\end{array}$ & $\begin{array}{c}\text { Kons. Maks } \\
\left(\mu \mathrm{g} / \mathrm{m}^{3}\right)\end{array}$ & $\begin{array}{c}\text { Jarak Kons. } \\
\text { Maks }(\mathrm{m})\end{array}$ \\
\hline 10 & 7,189 & 1300 & 2,785 & 1600 & 1,625 & 1900 \\
\hline 30 & 3,36 & 1600 & 1,279 & 2100 & 0,736 & 2400 \\
\hline 60 & 2,099 & 1800 & 0,8114 & 2300 & 0,4496 & 2900 \\
\hline 90 & 1,625 & 1900 & 0,5987 & 2500 & 0,3127 & 3500 \\
\hline 120 & 1,279 & 2100 & 0,4747 & 2800 & 0,2436 & 3500 \\
\hline 250 & 0,6679 & 2500 & 0,2411 & 3500 & 0,1143 & 5000 \\
\hline
\end{tabular}


Pada Tabel 1, dapat diperlihatkan bahwa semakin tinggi kecepatan laju alir emisi gas buang, akan mengakibatkan konsentrasi maksimum di tingkat ground level akan menurun tetapi jarak konsentrasi maksimum menjadi jauh di setiap diameter cerobong. Pada Tabel 1 juga diperlihatkan bahwa pada tinggi dan temperatur gas buang yang sama ( $180 \mathrm{~m}$ dan $323^{\circ} \mathrm{K}$ ) dengan kecepatan laju alir emisi gas buang tetap (10 m/dt), terlihat bahwa semakin kecil diameter cerobong konsentrasi maksimum akan semakin tinggi tetapi jarak maksimum akan semakin pendek.

Pada Tabel 2, dapat diperlihatkan bahwa dengan tinggi yang sama dengan Tabel $1(180 \mathrm{~m})$, tetapi temperatur gas buang yang berbeda $\left(373^{\circ} \mathrm{K}\right)$ dengan variasi kecepatan laju alir emisi gas buang dan diameter cerobong, terlihat fenomena yang sama bahwa semakin rendah diameter cerobong konsentrasi maksimum akan semakin tinggi tetapi jarak maksimum akan semakin rendah. Demikian juga semakin tinggi kecepatan laju alir emisi gas buang, akan mengakibatkan konsentrasi maksimum di tingkat ground level akan menurun di setiap variasi diameter. Pada Tabel 1 dan Tabel 2, dapat diperlihatkan bahwa dengan variasi kecepatan laju alir emisi gas buang dan diameter cerobong yang sama tetapi berbeda temperatur $323^{\circ} \mathrm{K}$ dan $373^{\circ} \mathrm{K}$, ternyata semakin tinggi temperatur konsentrasi maksimum di tingkat ground level akan mengalami penurunan.

Tabel 2. Hasil pemodelan dengan skenario tinggi cerobong 180 meter dengan variasi diameter dan variasi kecepatan alir gas buang pada temperatur $373^{\circ} \mathrm{K}$

\begin{tabular}{|c|c|c|c|c|c|c|}
\hline \multirow{2}{*}{ SKENARIO } & \multicolumn{6}{|c|}{ Diameter Cerobong $(\mathrm{m})$} \\
\cline { 2 - 7 } & \multicolumn{2}{|c|}{10} & \multicolumn{2}{c|}{20} & \multicolumn{2}{c|}{30} \\
\hline $\begin{array}{c}\text { Kecepatan Laju Alir } \\
\begin{array}{c}\text { Emisi gas buang } \\
(\mathrm{m} / \mathrm{dt})\end{array}\end{array}$ & $\begin{array}{c}\text { Kons. Maks } \\
\left(\mu \mathrm{g} / \mathrm{m}^{3}\right)\end{array}$ & $\begin{array}{c}\text { Jarak Kons. } \\
\text { Maks }(\mathrm{m})\end{array}$ & $\begin{array}{c}\text { Kons. Maks } \\
\left(\mu \mathrm{g} / \mathrm{m}^{3}\right)\end{array}$ & $\begin{array}{c}\text { Jarak Kons. } \\
\text { Maks }(\mathrm{m})\end{array}$ & $\begin{array}{c}\text { Kons. Maks } \\
\left(\mu \mathrm{g} / \mathrm{m}^{3}\right)\end{array}$ & $\begin{array}{c}\text { Jarak Kons. } \\
\text { Maks }(\mathrm{m})\end{array}$ \\
\hline 10 & 4,121 & 1500 & 1,591 & 1900 & 0,8623 & 2400 \\
\hline 30 & 1,864 & 1900 & 0,7195 & 2400 & 0,3991 & 2900 \\
\hline 60 & 1,151 & 2100 & 0,4423 & 2800 & 0,214 & 4000 \\
\hline 90 & 0,1446 & 4500 & 0,8623 & 2400 & 0,0754 & 3000 \\
\hline 120 & 0,7195 & 2400 & 0,2373 & 3500 & 0,1122 & 5000 \\
\hline 250 & 0,4268 & 2800 & 0,1209 & 5000 & 0,0376 & 5000 \\
\hline
\end{tabular}

Selanjutnya fenomena yang sama bila kita melakukan empat skenario di atas pada tinggi cerobong 240 $\mathrm{m}$, variasi kecepatan laju alir emisi gas buang $10 \mathrm{~m} / \mathrm{s}-240 \mathrm{~m} / \mathrm{s}$, diameter cerobong $10 \mathrm{~m}-30 \mathrm{~m}$ dan temperatur gas buang $323^{\circ} \mathrm{K}-373^{\circ} \mathrm{K}$ dan data tersebut dapat diihat pada Tabel 3 dan Tabel 4. Dengan hasil semakin tinggi kecepatan laju alir emisi gas buang, akan mengakibatkan konsentrasi maksimum di tingkat ground level akan menurun di setiap variasi diameter. Pada Tabel 1 hingga Tabel 4 dapat dipredikasi bahwa konsentrasi maksimum konsentrasi tertinggi di tingkat ground level dengan ke empat skenario ternyata diperoleh pada jarak $1300 \mathrm{~m}-1500 \mathrm{~m}$. Selanjutnya dengan melakukan variasi temperatur gas buang $323^{\circ} \mathrm{K}$ dan $373^{\circ} \mathrm{K}$, ternyata akan mempengaruhi maksimum konsentrasi tertinggi di tingkat ground level, tetapi jarak dimana konsentrasi tertinggi tetap pada jarak $130 \mathrm{~m}-1500 \mathrm{~m}$.

Berdasarkan data ANDAL PT SUMBER SEGARA PRIDANA ${ }^{(6)}$, ternyata profil PLTU-Jateng II dengan kebutuhan 8000 ton/hari, dengan asumsi abu layang yang keluar dari cerobong sebesar 8,1\% maka didapat laju emisi debu sebesar 33,75 gr/dt yang keluar dari cerobong. Berdasarkan data ANDAL pada bulan April 2011 PLTU-Jateng II mempunyai kecepatan laju alir emisi rata-rata 2,424 m/dt, ketinggian cerobong $210 \mathrm{~m}$, diameter cerobong 7,2 $\mathrm{m}$ dan temperatur gas buang sebesar $439,9^{\circ} \mathrm{K}$. Dari data lapangan tersebut kita buat modeling distribusi polutan dan kita bandingkan dengan data simulasi dari Tabel 1 sampai 4, dengan perangkat lunak SCREEN3 dan hasilnya kita tampilkan pada Gambar 1. 
Tabel 3. Hasil pemodelan dengan skenario tinggi cerobong 240 meter dengan variasi diameter dan variasi kecepatan alir gas buang pada temperatur $323^{\circ} \mathrm{K}$

\begin{tabular}{|c|c|c|c|c|c|c|}
\hline \multirow{2}{*}{ SKENARIO } & \multicolumn{3}{|c|}{ Diameter Cerobong $(\mathrm{m})$} \\
\cline { 2 - 7 } & \multicolumn{2}{|c|}{10} & \multicolumn{2}{c|}{20} & \multicolumn{2}{c|}{30} \\
\hline $\begin{array}{c}\text { Kecepatan Laju Alir } \\
\text { Emisi (m/dt)) }\end{array}$ & $\begin{array}{c}\text { Kons. Maks } \\
\left(\mu \mathrm{g} / \mathrm{m}^{3}\right)\end{array}$ & $\begin{array}{c}\text { Jarak Kons. } \\
\text { Maks }(\mathrm{m})\end{array}$ & $\begin{array}{c}\text { Kons. Maks } \\
\left(\mu \mathrm{g} / \mathrm{m}^{3}\right)\end{array}$ & $\begin{array}{c}\text { Jarak Kons. } \\
\text { Maks }(\mathrm{m})\end{array}$ & $\begin{array}{c}\text { Kons. Maks } \\
\left(\mu \mathrm{g} / \mathrm{m}^{3}\right)\end{array}$ & $\begin{array}{c}\text { Jarak Kons. } \\
\text { Maks }(\mathrm{m})\end{array}$ \\
\hline 10 & $\mathbf{6 , 2 1 4}$ & 1400 & 2,601 & 1600 & 1,501 & 1900 \\
\hline 30 & 3,035 & 1700 & 1,199 & 2100 & 0,7004 & 2400 \\
\hline 60 & 1,926 & 1900 & 0,7705 & 2300 & 0,4357 & 2800 \\
\hline 90 & 1,501 & 1900 & 0,5765 & 2500 & 0,3054 & 3000 \\
\hline 120 & 1,199 & 2100 & 0,4586 & 2800 & 0,2405 & 3500 \\
\hline 250 & 0,6399 & 2500 & 0,2383 & 3500 & 0,115 & 5000 \\
\hline
\end{tabular}

Tabel 4. Hasil pemodelan dengan skenario tinggi cerobong 240 meter dengan variasi diameter dan variasi kecepatan alir gas buang pada temperatur $373^{\circ} \mathrm{K}$

\begin{tabular}{|c|c|c|c|c|c|c|}
\hline \multirow{2}{*}{ SKENARIO } & \multicolumn{3}{|c|}{ Diameter Cerobong $(\mathrm{m})$} \\
\cline { 2 - 7 } $\begin{array}{c}\text { Kecepatan Laju Alir } \\
\text { Emisi (m/dt) }\end{array}$ & $\begin{array}{c}\text { Kons. Maks } \\
\left(\mu \mathrm{g} / \mathrm{m}^{3}\right)\end{array}$ & $\begin{array}{c}\text { Jarak Kons. } \\
\text { Maks }(\mathrm{m})\end{array}$ & $\begin{array}{c}\text { Kons. Maks } \\
\left(\mu \mathrm{g} / \mathrm{m}^{3}\right)\end{array}$ & $\begin{array}{c}\text { Jarak Kons. } \\
\text { Maks }(\mathrm{m})\end{array}$ & $\begin{array}{c}\text { Kons. Maks } \\
\left(\mu \mathrm{g} / \mathrm{m}^{3}\right)\end{array}$ & $\begin{array}{c}\text { Jarak Kons. } \\
\text { Maks }(\mathrm{m})\end{array}$ \\
\hline 10 & 3,657 & 1500 & 1,47 & 1900 & 0,8202 & 2400 \\
\hline 30 & 1,725 & 2000 & 0,6855 & 2500 & 0,3866 & 2900 \\
\hline 60 & 1,1 & 2200 & 0,4266 & 2800 & 0,2114 & 4000 \\
\hline 90 & 0,8202 & 2400 & 0,2993 & 3500 & 0,1475 & 4500 \\
\hline 120 & 0,6855 & 2500 & 0,2347 & 3500 & 0,1131 & 5000 \\
\hline 240 & 0,4123 & 2800 & 0,1214 & 5000 & 0,0405 & 5000 \\
\hline
\end{tabular}

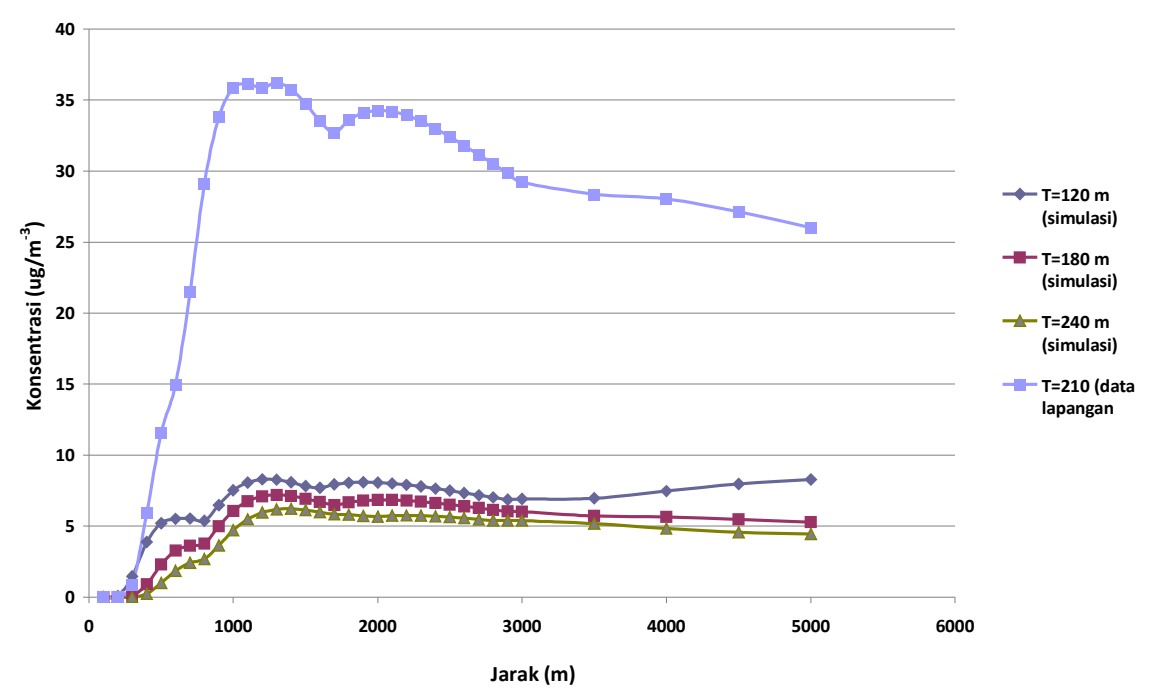

Gambar 3. Perbandingan modeling distribusi polutan antara masukan data simulasi dan lapangan pada perangkat lunak "SCREEN3". 
Pada Gambar 3, dapat diperlihatkan bahwa perbandingan masukan data antara simulasi dan lapangan dengan perangkat lunak "SCREEN3". Pada Gambar 3 tersebut terlihat bahwa maksimum konsentrasi tertinggi di tingkat ground level pada hasil masukan simulasi diantara $1300 \mathrm{~m}-1500 \mathrm{~m}$, sedangkan masukan memakai data lapangan didapat diantara 1200 m-1400 m. Maka berdasarkan hasil pada Tabel 1 sampai dengan Tabel 4 dan Gambar 3, dapat kesimpulan bahwa jarak sampling terbaik dilakukan pada jarak diantara $1200 \mathrm{~m}-1500 \mathrm{~m}$ dari cerobong PLTU.

\section{Prediksi Stabilitas Meteorologi}

Stabilitas meteorologi di suatu daerah akan mempenguruhi kualitas sampling udara. Stabilitas meteorologi tersebut akan dipengaruhi beberapa faktor seperti kecepatan angin dan intensitas sinar matahari (malam/siang). Berdasarkan PRATAMA ${ }^{(17)}$ terdapat beberapa klasifikasi stabilitas meteorologi, (1) kelas A (sangat tidak stabil), (2) kelas B (tidak stabil), kelas C (sedikit tidak stabil), kelas D (netral), kelas E (agak sedikit stabil) dan kelas $\mathrm{F}$ (stabil). Pada Gambar 4 dan Gambar 5, merupakan gambaran kecepatan angin berupa grafik cakra angin, yang dibuat dari data Badan Meteorologi Klimatologi dan Geofisika (BMKG) daerah Cilacap pada bulan Juni tahun 2010 dan 2011. Pada Gambar 4 dapat diperkirakan bahwa tahun 2010 yang lalu terlihat arah angin berubah-ubah terbesar dari arah tenggara, kemudian timur dan sedikit ke arah selatan dengan kecepatan yang berubah-ubah pula disetiap waktu. Kemudian pada Gambar 5, arah angin pada Juni 2011, lebih stabil dan dominan dan arah angin datang bertiup dari arah tenggara sebesar $58 \%$ dengan kecepatan 11-17 knot. Karena kecepatan konstan dari arah tenggara dengan rata-rata 11-17 knot, maka diambil kesimpulan bahwa waktu sampling terbaik di bulan Juni 2011. Selanjutnya karena arah tenggara PLTU adalah wilayah laut, maka pengambilan sampling dilakukan di tiga daerah yaitu Barat, Timur dan Utara PLTU Jateng II. Prediksi stabilitas meteorologi di bulan Juni 2010 dan 2011 dapat dilihat pada Gambar 4 dan 5.

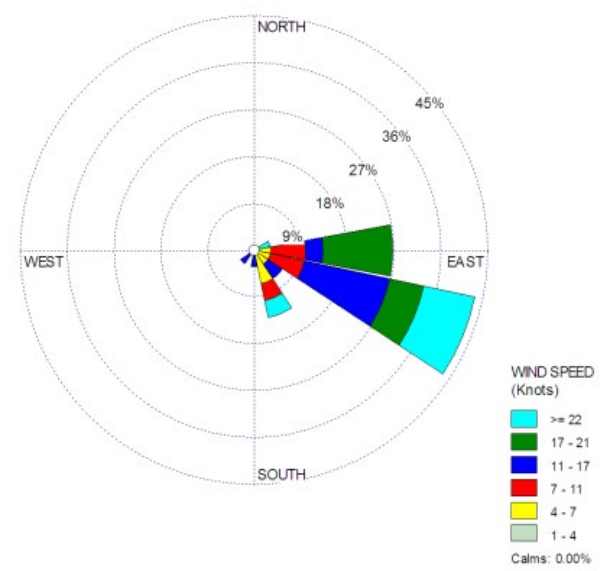

Ganbar 4. Arah dan kecepatan angin Juni 2010

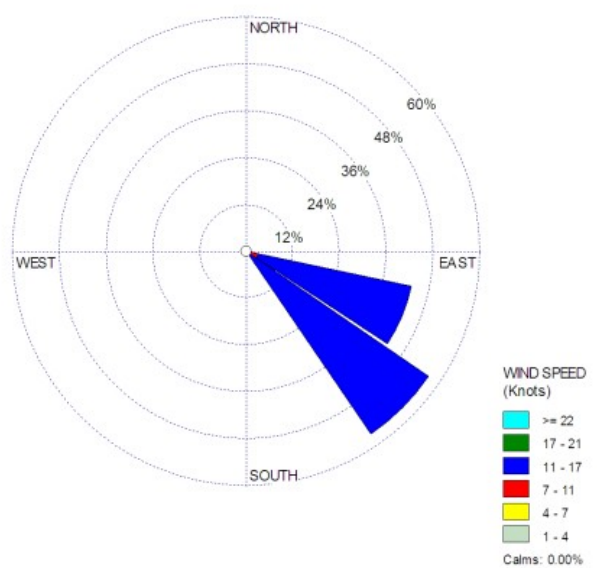

Gambar 5. Arah dan kecepatan angin Juni 2011

Berdasarkan data ANDAL PT SUMBER SEGARA PRIDANA( ${ }^{(6)}$, pada Gambar 6 merupakan hasil prediksi stabilitas meteorologi di bulan Juni 2011 yang dibuat dengan perangkat lunak "SCREEN3". Pada Gambar 6 dapat diperlihatkan bahwa hubungan antara konsentrasi polutan maksimum di tingkat ground level $\left(\mathrm{ug} / \mathrm{m}^{3}\right)$ dengan jarak $(\mathrm{m})$ yang dihitung dari cerobong PLTU Cilacap. Selanjutnya bila diambil pada kecepatan terendah $11 \mathrm{knot}$ atau 5,6 m/dt, maka stablitas meteorologi di bulan Juni 2011 yang dibuat dengan pemodelan memakai "SCREEN3" diperkirakan diantara tipe B, B-C , C dan sedikit kearah tipe $D^{(10)}$, dengan jarak pengambilan sampling $1200 \mathrm{~m}-2000 \mathrm{~m}$. Ternyata hal ini tidak menyalahi prediksi jarak pengambilan sampling yang telah disimulasikan pada Tabel 1 sampai 4 dan Gambar 3. 


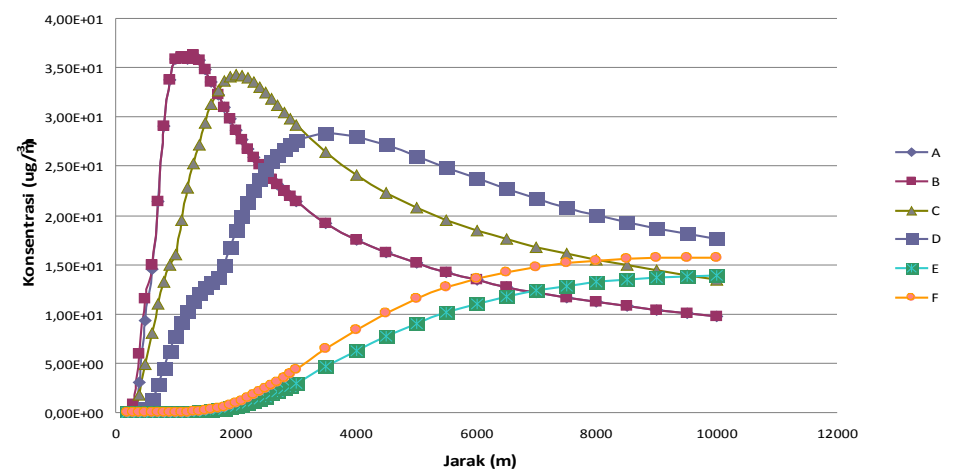

Gambar 6. Prediksi stabilitas meteorologi bulan Juni 2011 dengan pemodelan memakai "SCREEN3"

\section{Aktivitas Radionuklida PM 2,5 dan PM 10}

Dengan mengadopsi metoda pengukuran dari IMS-CTBO ${ }^{(13)}$, dan memakai alat High Volume Air Sampler (HVS) model TFIA-2, CKHV810 STAPLEX Air Sampler buatan U.S.A, serta filter dipakai jenis TFA810 dan hasil identifikasi radionuklida pada PM 2,5 dan PM 10 dapat di lihat pada Gambar 7 dan 8.

Dari Gambar 7 didapatkan hasil aktivitas radionuklida PM2,5 sekitar PLTU Cilacap di tiga tempat yaitu Barat, Utara dan Timur. Untuk analisis sampel udara dengan ukuran $\mathrm{PM}_{2,5}$ di ketiga tempat menggunakan spektrometer gamma ditemukan 6 macam radionuklida yaitu Ac-228, TI-208, Pb-212, Ra-226, dan Bi-214. Pada Gambar 7, ternyata radionuklida Bi-214 dalam sampel udara hanya terdapat di bagian Barat dari PLTU-Jateng II. Karena radionuklida Bi-214 merupakan anak luruh dari U-238, maka kemungkinan daerah barat paling tercemar oleh U-238 dari pada yang lain.

Untuk analisis sampel udara dengan ukuran PM10 (Gambar 8) di ketiga tempat sampling menggunakan spektrometer gamma ditemukan juga 6 macam radionuklida yaitu Ac-228, TI-208, Pb-212, Ra-226, Bi-214 dan K-40. Hasil analisis aktivitas dengan PM 10, ternyata baik di sebelah barat, utara dan timur terdapat radionuklda $\mathrm{Bi}-214$ dengan aktivitas paling tinggi pada daerah barat. Jadi keberadaan radionuklida Bi-214 di dalam filter PM 2,5, kemungkinan merupakan sisa rembesan dari hasil isapan filter PM 10. Dari hasil perhitungan pada Gambar 7 dan 8 didapatkan informasi bahwa aktivitas radionuklida terbesar di sampel udara PLTU-Jateng II pada PM2,5 dan PM10 adalah Ra-226 adalah Ra-226.

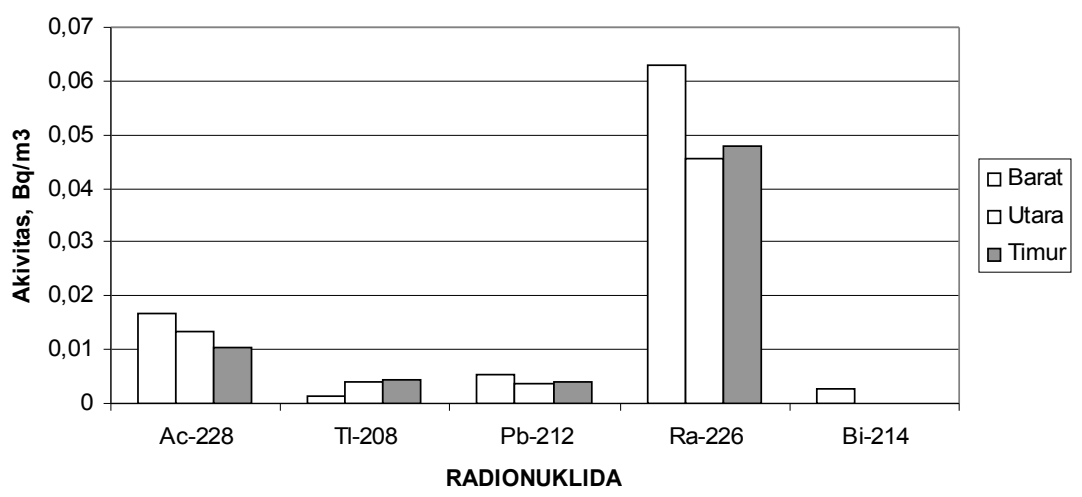

Gambar 7. Hasil identifikasi filter PM 2,5 dengan spektrometri Y

Selanjutnya apabila dilihat dari hasil aktivitas radionuklida di lingkungan PLTU-Jateng II baik itu pada filter PM 2,5 dan PM 10 dibandingkan dengan Baku Mutu yang dikeluarkan oleh BAPETEN 02/Ka-BAPETEN/V99 yaitu rata-rata aktivitas radionuklida sebesar $0,1 \mathrm{~Bq} / \mathrm{m}^{3}$ udara. Maka aktivitas radionuklida dari hasil emisi pembakaran batubara di PLTU -Jateng II masih jauh dari batas ambang yang diperbolehkan. Namun untuk radionuklida Ac-228 di bagian Barat dan Utara baik ukuran PM 10 dan PM 2,5 cukup mendekati dari batas ambang yang dianjurkan oleh Badan Pengawas Tenaga Nuklir (BAPETEN) yaitu 0,02 Bq/ $\mathrm{m}^{3}$ udara. 
Pada Gambar 9, dapat diperkirakan bahwa baik pada wilayah barat, Utara dan Timur PLTU Cilacap terdapat radionuklida K-40 baik itu pada filter PM 10 atau PM 2,5. Hasil identifikasi tersebut ternyata aktivitas radionuklida K-40 di sebelah Barat > Timur > Utara dan harga aktivitas pada fillter PM 2,5 kandungan K-40 lebih tinggi dari pada di filter PM 10. Hal ini menunjukkan bahwa partikulat PM 2,5 relatif banyak menangkap radionuklida K-40 dari pada PM 10, dari hasil pembakaran batubara dan terdispersi oleh cerobong sebagai abu layang.

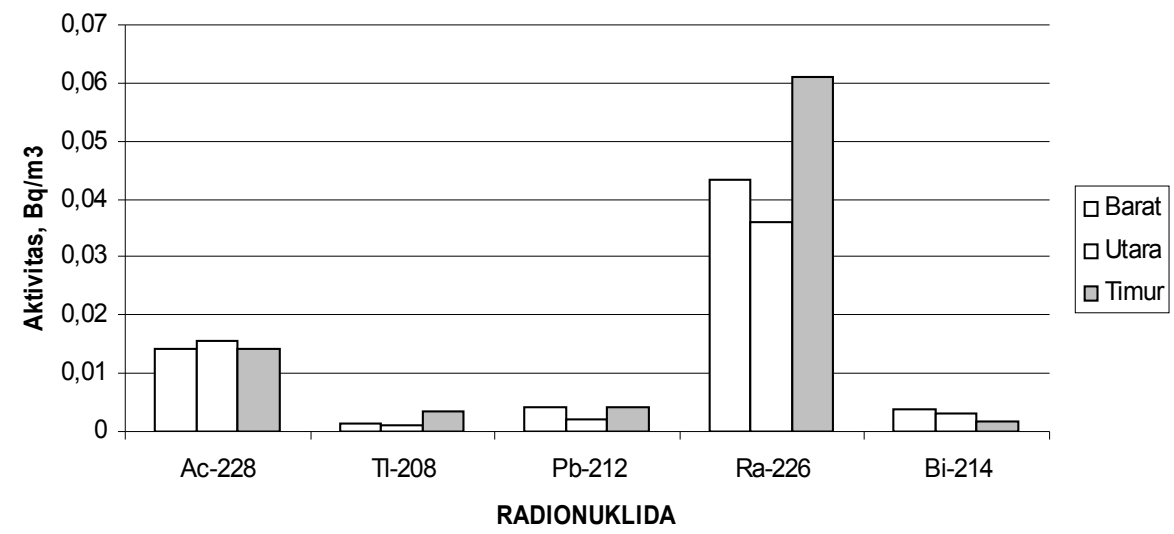

Gambar 8. Hasil identifikasi filter PM 10 dengan spektrometri y

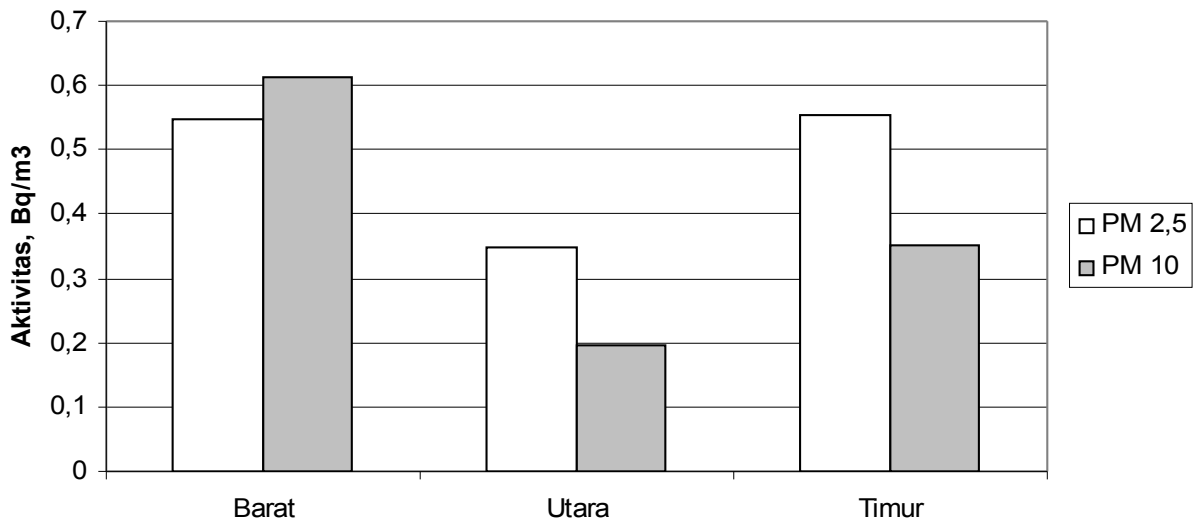

Gambar 9. Hasil identifikasi filter PM 10 dengan spektrometri y

\section{KESIMPULAN}

Dengan memakai perangkat lunak "SCREEN3" dan "WRPLOT" sampling udara di daerah sekitar PLTU Jateng II dapat ditentukan pada bulan Juni 2011 dengan jarak pengambilan diantara $1300 \mathrm{~m}-1500 \mathrm{~m}$. Hasil prediksi stablitas meteorologi di bulan Juni 2011 yang dibuat dengan pemodelan memakai "SCREEN3" diperkirakan mempunyai diantara tipe B, B-C , C dan sedikit kearah tipe D. Hasil aktivitas filter PM 10 dan PM 2,5 di ketiga tempat pengambilan sampling menggunakan spektrometer gamma telah ditemukan 6 macam radionuklida yaitu Ac-228, TI-208, Pb-212, Ra-226, Bi-214 dan K-40. Dari hasil perhitungan diperoleh bahwa aktivitas radionuklida tertinggi pada sampel udara PLTU Jateng II untuk PM 2,5 dan PM 10 adalah Ra-226 dengan masing-masing aktivitas diantara $0,04-0,06 \mathrm{~Bq} / \mathrm{m}^{3}$ udara. 


\section{DAFTAR PUSTAKA}

1. WIDI SETIAWAN Iptek Nuklir Untuk Energi, Presentasi IImiah pada Ulang Tahun BATAN di PTAPB. Yogyakarta, Desember 2008

2. HENI S., "Dampak Radioaktif Penggunaan Energi Fosil Batubara dan Energi Nuklir di Pusat Pembangkit Listrik"., Prosiding Seminar Nasional ke-12 Teknologi dan Keselamatan PLTN Serta Fasilitas Nuklir., Yogyakarta, (2006), 384-396

3. MAROVIC.G., SENCAR.J., KOVAC.J., PRLIC.I., (2004), Improvement of the radiological environmental situation due to remedial actions at a coal power plan, Journal of Radioanalytical and Nuclear Chemistry., Vol.161, No 2, , pp. 451-455.

4. FLUES.M., CAMARGO.I.M.C., SILVA.P.S.C., MAZZILLI.B.P., Radioactivity of coal and ashes from Figuera coal power plant in Brazil, Journal of Radioanalytical and Nuclear Chemistry., Vol.270, No 3, (2006), 597-602.

5. PAPASTEFANOU.C., Escaping radioactivity from coal-fired power plants (CPPS) due to coal burning and the associated hazards: a review., Journal of Environmental Radioactivity., Vol.101, 3, (2010), 191200.

6. PT SUMBER SEGARA PRIMADAYA., Analisis Dampak Lingkungan (ANDAL) Pembangunan PLTU Cilacap 2x 300 MW, di desa Karangkandri dan Menganti kecamatan Kesugihan Kabupaten Cilacap Provinsi Jawa Tengah., PT Sumber Segara Primadaya (2004).

7. SAYED.A.M., AL-AZMI.D., KHURAIBET.N.A, Measurement of $\mathrm{Pb}-210$ concentration in airborn in Kuwait., Enviromental Monitoring and Assessment , V.79, (2002), 47-55.

8. KAM.E., BOZKURT.A., ILGAR.R., A study of background radioactivity level for Canakkale, Turkey, Enviromental Monitoring and Assessment , V.168, (2010), 685-690.

9. CEVIK.U.,DAMLA.N., NEZIR.S., Radiological characterization of Cayırhan coal-fired power plant in Turkey., FUEL,V.86, 16, (2007), 09-2513

10. JESSEL.L,CRISTIANE.L,JOHNSON.M.A., User's Guide of Screen View, version 2.5.0, Screening Air Dispersion Model (Screen3), Lake Environmental software, (2007).

11. JESSEL.L,CRISTIANE.L,JOHNSON.M.A., User's Guide of Rammet View, , Lake Environmental software, (2011)

12. MUZAKKY, AGUS T, Application of high-volume sampler for Atmospheric Radionuclides Sampling In Rembang Coal-Fire Power Plant (RCPP), Indonesia., Indonesian Journal Of Chemistry., (Process Printing) (2011).

13. WERZI.R., The operational status of the IMS radionuclide particulate network., Journal of Radioanalytical and Nuclear Chemistry., DOl.10.1007/s 10967-009-0270-9 (2009).

14. BRACET.G., Implementation of radionuclide measurements for the Comprehensive Nuclear-Test Ban Treaty and associated on site inspection., Journal of radioanalytical and nuclear chemistry., Vol. 248., No3., (2001), 583-585.

15. KARHU.P., Radionuclide monitoring as part of the verification regime for the Comprehensive NuclearTest Ban Treaty., Radiochemistry, Vol 43,No 5, (2001) 455-4557.

16. PADOANI.F., CELLA.L., SHEN.X., WERZI.R., Testing and provisional operation of the IMS radionuclide monitoring network., Journal of radioanalytical and nuclear chemistry, Vol.276, no.2., (2008), 461-466.

17. PRATAMA.D.S., SUGIHARTO.E., SISWANTA.D., "Modelling studies air pollution dispersions supporting tool for new power plant environmental impact assessment"., Proceeding of International Conference on Chemical Science (ICCS-2007)., Jointed UGM-USM Yogyakarta-Indonesia, (2007), 1-9. 